\title{
Early recruitment dynamics in tropical restoration
}

\author{
Marinés de la Peña-Domene, ${ }^{1,3}$ Cristina Martínez-Garza, ${ }^{2}$ and Henry F. Howe ${ }^{3,4}$ \\ ${ }^{1}$ Facultad de Ciencias, Universidad Nacional Autónoma de México, Mexico City 04510 Mexico \\ ${ }^{2}$ Centro de Investigación en Biodiversidad y Conservación, Universidad Autónoma del Estado de Morelos, \\ Cuernavaca, Morelos 62209 Mexico \\ ${ }^{3}$ Department of Biological Sciences, University of Illinois at Chicago $(\mathrm{m} / \mathrm{c} 066)$, Chicago, Illinois 60607 USA
}

\begin{abstract}
Unassisted secondary succession in abandoned tropical pastures often results in species-poor forests of pioneer trees that persist for decades. We characterize recruitment rates of woody vegetation in planting treatments during the first 60 months of experimental restoration on thin, eroded soils at Los Tuxtlas, southern Mexico. We test the hypothesis that recruitment of later-successional trees is greater in fenced plots planted with native trees than in fenced controls that simulate natural succession, and further that recruitment of such species would be greater in plots planted with animal-dispersed trees than in those planted with wind-dispersed trees.

Results indicated much greater recruitment of later-successional animal-dispersed trees in planted plots as compared with controls. Three censuses per year recorded 960 recruited individuals of 44 species of trees and shrubs from 20-60 months after cattle exclusion. Ninetysix percent of recruits were not of planted species. Repeated-measures analyses of variance indicated that recruited communities included more species of pioneers than of latersuccessional trees and shrubs, with more individuals and species dispersed by animals than by wind. Recruitment of pioneers did not differ between control and planted plots. Latersuccessional recruits dispersed by animals accumulated $>10$ times faster in planted than control plots, with apparent acceleration after planted Cecropia obtusifolia and Ficus yoponensis first produced fleshy fruits 48 months after cattle exclusion. Sparse latersuccessional wind-dispersed recruits did not differ by treatment. Our preliminary results over the first five years after cattle exclusion indicate that planted stands clearly accelerate succession through accumulation of later-successional trees and shrubs dispersed by animals.
\end{abstract}

Key words: dispersal mode; experimental restoration; life history; Mexico; movement ecology; seed dispersal; seedling establishment; succession; tropical rainforest.

\section{INTRODUCTION}

The relationship between deforestation and forest regeneration will determine the future of tropical biomes. Tropical forests have the highest biodiversity of all terrestrial ecosystems (Turner 1996, Dirzo 2001), yet total deforestation and forest fragmentation are rapidly destroying much of the remaining old-growth forest between the Tropic of Capricorn and the Tropic of Cancer (Houghton 1994, Ojima et al. 1994, Bryant et al. 1997, Fahrig 2003, Fearnside 2005). Less appreciated is the rapid growth of secondary forest on land that has been abandoned (Chazdon 2003, Rudel et al. 2005, Wright 2010). Assisted regeneration and full-scale forest restoration have potentially important roles in regaining lost biodiversity and ecosystem services. A challenge, addressed here, is to test means of accelerating revegetation of patches to connect forest fragments in permanent agricultural mosaics where substantial land

Manuscript received 7 October 2012; accepted 18 December 2012; final version received 23 January 2013. Corresponding Editor: R. L. Knight.

${ }^{4}$ Corresponding author. E-mail: hfhowe@uic.edu area will not be abandoned to natural succession or set aside for ecological restoration.

Natural succession occurs at different rates under different circumstances. Succession is slower in abandoned pasture than on land with histories of subsistence agriculture, or logged areas that are allowed to recover without further disturbance (Aide et al. 1995). Highintensity, long-term cattle ranching slows ecosystem capacity to recover biodiversity (Uhl et al. 1988, Nepstad et al. 1991, Jones et al. 2003, Myster 2004, Benítez-Malvido and Lemus-Albor 2005). Depleted seed banks, compacted soil, depleted soil nutrients, intense solar radiation, low seed input, and high rates of seed and seedling predation limit recolonization and growth by late-successional forest trees. Pastures under continued cattle grazing do not regenerate forest.

The rate of recovery of forest richness in abandoned pasture is influenced by dispersal mode and life history of colonizing plants. Small seeds carried long distances by wind, often of a few ubiquitous species, arrive unassisted in disturbed areas (Janzen 1988, Ingle 2003, Howe et al. 2010). A paradox and a challenge for recovery of tropical diversity on badly degraded land is that the great majority of tropical rain forest trees and 
shrubs are dispersed by animals (e.g., Frankie et al. 1974, Howe and Smallwood 1982, Wang and Smith 2002), yet many birds and mammals of the forest interior avoid crossing open areas, or require unusual motivation to do so. Most animal-dispersed seeds of forest interior do not arrive in extensive pastures until their dispersal agents seek cover or food in isolated trees or small stands of trees (Estrada and Coates-Estrada 2001, 2005). A generalization across the tropics seems to be that large open areas of grasses on thin, eroded soils are slow to recover by unassisted succession because of severe dispersal limitation and adverse conditions for seeds and germinating seedlings.

Here we report seedling establishment by life history and dispersal mode in pasture plots for the first five years of an experiment expected to last 30 years. We hypothesize that mixed plantings of native trees accelerate assisted compared to natural succession (reviewed in Martínez-Garza and Howe 2003). In early stages of succession, planted early successional species (fruiting pioneers as contrasted with later-successional species; see Methods) accelerate recruitment of primaryforest species that may not otherwise establish in pasture for years to decades. One compelling question is whether these plantings shape the structure of the recruited communities more than would occur by unassisted succession. Another question, to be addressed as our experimental plantings mature, is whether recruitment differs in different kinds of plantings.

We test the effects of planting treatments, life-history, and dispersal mode on recruitment rates in the first 60 months after cattle exclusion. We expect an overall increase of recruitment rates, especially for pioneer species with small mobile seeds. We hypothesize that recruitment by animal-dispersed species will be higher under plantings than in fenced but unplanted plots that simulate natural succession. We further hypothesize that wind-dispersed recruits will not show distinctive recruitment patterns based on treatments prior to maturation of planted species. Ultimately, as numerous experimental animal-dispersed trees mature and provide food for wide-ranging animals that eat fruit and disperse seeds, we expect dramatically higher recruitment of forest species in plantings of animal-dispersed than plantings of wind-dispersed trees. The surprise at five years is that individual recruitment of later-successional trees dispersed by animals is much higher in planted plots than is recruitment of pioneers in any treatment; even sparse, non-reproductive tree plantings play an important role in re-establishing biodiversity of later-successional trees.

\section{Methods}

\section{Study area and species}

This study was conducted at Los Tuxtlas, Veracruz, Mexico $\left(18^{\circ} 05^{\prime} 18 \mathrm{~N}\right.$ and $18^{\circ} 45^{\prime} \mathrm{N} ; 94^{\circ} 35^{\prime} \mathrm{W}$ and $95^{\circ} 30^{\prime}$ W). The Los Tuxtlas forest is $3300 \mathrm{~km}^{2}$ in area and ranges in elevation from 200 to $1700 \mathrm{~m}$ above sea level (Dirzo et al. 1997). This volcanic region is characterized by acidic soils $(\mathrm{pH} 4.9)$ with a large clay component ( $48.5 \%$ clay), having formed from basaltic and andesitic rock mixed with volcanic ash (see Guevara et al. 2004). Records of the Los Tuxtlas Biological Station of the Universidad Nacional Autónoma de México show mean annual precipitation of $4825 \mathrm{~mm}$ per year from 1997 to 2006 (Martínez-Garza et al. 2011), a rainy season from June to February and a dry season from March to May, and a mean annual temperature of $25^{\circ} \mathrm{C}$ (see Soto and Gama 1997). The formerly forested land in which our plots were established has been under intensive cattle ranching for at least 30 years on ground planted with native (Axonopus compressus and Paspalum conjugatum) and exotic (Cynodon dactylon, Brachiaria brizantha, Brachiaria decumbens, and Panicum spp.) grasses. Soil depth ranges from 5 to $72 \mathrm{~cm}$ over volcanic rock, with a mean depth of $26.8 \pm 14.2 \mathrm{~cm}$ (mean $\pm \mathrm{SD}$ ) (Howe et al. 2010, Tobón et al. 2011). Nearby forest holds $\sim 300$ native tree species (Ibarra-Manriquez and Sinaca 1995, $1996 a, b)$. In Los Tuxtlas landscapes, $81 \%$ of 364 sampled plant species occur in fragments $<5$ ha; $58 \%$ of species in small fragments in even the most highly fragmented areas are old-growth trees (Arroyo-Rodríguez et al. 2008). More than 150 fruit-eating birds and mammals occupy the Los Tuxtlas landscape (Estrada et al. 1993), with wide-ranging fruit-eating bats (e.g., Artibeus spp., Sturnira spp.) and birds (Dryocopus lineatus, Gymnostinops montezuma, Psilorhinus morio, Ramphastos sulfuratus) among the most likely dispersal agents of seeds arriving in our developing planted stands (H. F. Howe, unpublished data).

Planted and recruited species were classified as pioneer or later successional, and as animal dispersed or wind dispersed. Life-history designations are problematic where authors place the same species in different categories and use several categories (pioneer vs. persistent; early pioneer, late pioneer, vs. late successional; pioneer vs. old-growth; generalist vs. specialist; e.g., Martínez-Ramos 1985, Purata 1986, Ibarra-Manriquez and Oyama 1992, Arroyo-Rodríguez et al. 2008, Chazdon et al. 2011). Because the data at hand do not lend themselves to statistical distinctions of pasture recruits into several categories (cf. Chazdon et al. 2011 for secondary and primary forests), we use demographic and associational analyses from the Los Tuxtlas region to categorize species as "pioneers" common in early succession and other "later-successionals" (e.g., Purata 1986, Ibarra-Manriquez and Oyama 1992). This parallels the distinction by Arroyo-Rodríguez et al. (2008) and Howe et al. (2010) between pioneer and old-growth species.

Distinction of animal- and wind-dispersed species is straightforward. Animal-dispersed species are those with fleshy fruits with pulp surrounding seeds as drupes, berries, pomes, dehiscent capsules or indehiscent pods, as compared with wind-dispersed seeds with wings, balloons, plumes, or other structures that greatly increase surface-to-volume ratios (e.g., Howe and 


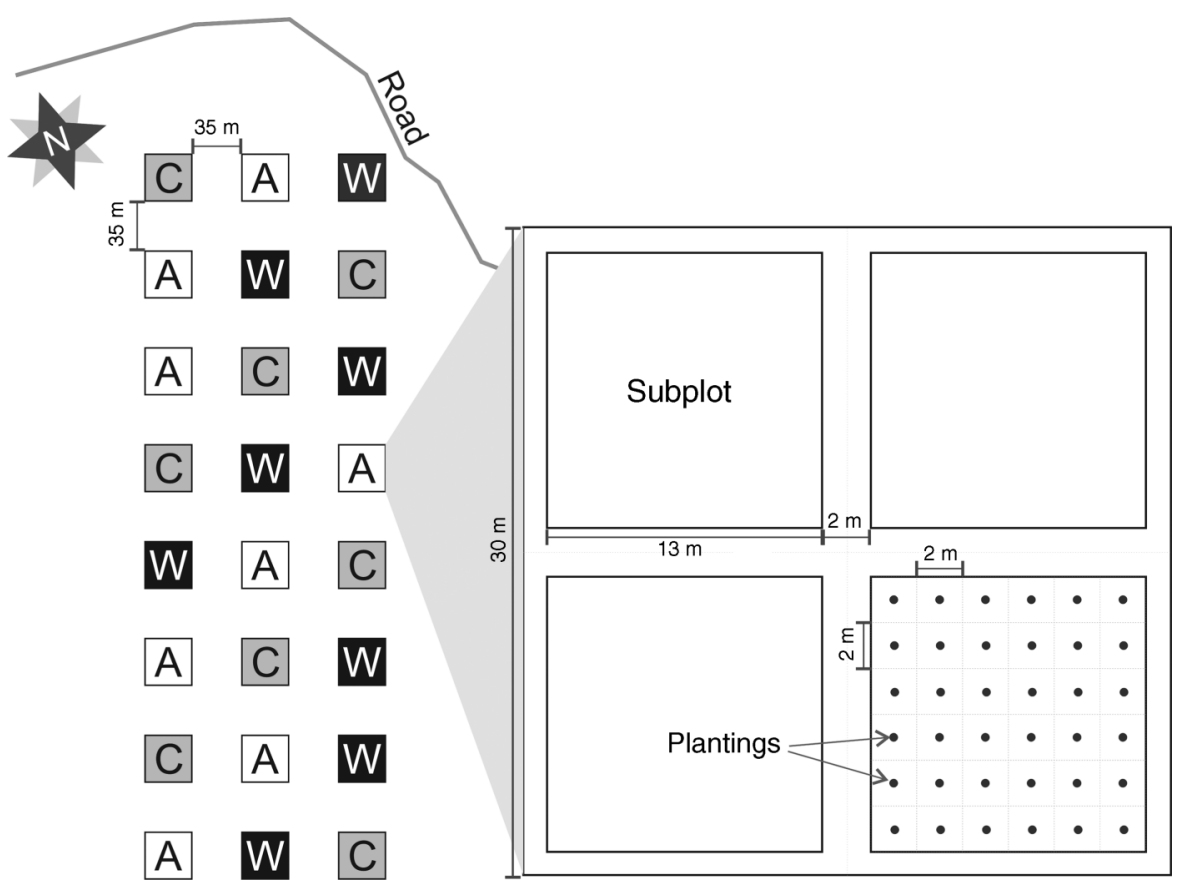

FIG. 1. Experimental design of fenced plots. Illustrated are plantings of 12 animal-dispersed species (A), 12 wind-dispersed species (W), and unplanted controls (C).

Smallwood 1982, van der Pij1 1982). Species with fruit structures consistent with water dispersal, ballistic dispersal, or hard nuts hoarded by rodents or dispersed by gravity are not present in the sample. Seeds are often re-dispsersed by secondary agents, but rodents likely to carry seeds substantial distances (e.g., the agouti, Dasyprocta mexicana) are not present in the plots.

\section{Experiment}

In June 2006, we established 24 cattle exclusion plots arrayed in a $3 \times 8$ grid in 12 ha of active pasture with a slope from 180 to $260 \mathrm{~m}$ above sea level. Remnant trees were removed during site preparation. Each $30 \times 30 \mathrm{~m}$ plot was subdivided into four $13 \times 13 \mathrm{~m}$ subplots available for seedling establishment, with $2 \mathrm{~m}$ crossed central aisles clear of woody vegetation and $1 \mathrm{~m}$ external edge cleared by cattle reaching through fences (Fig. 1). Plots were defined with three-strand fences of barbed wire fastened to living poles of Gliricidia sepium (Fabaceae), a gravity-dispersed tree that was trimmed regularly to prevent fruiting. Initial planting was between June and December 2006. Plots were replanted in September and October 2007 after an extended seasonal drought killed the first cohorts (Martínez-Garza et al. 2011). Eight exclosures were planted with 12 animal-dispersed species (four pioneer and eight later-successional tree species); another eight exclosures were planted with 12 winddispersed species (four pioneers and eight later-successional tree species; Appendix A). Eight unplanted exclosures served as controls. Each subplot was planted in a $6 \times 6$ grid, with a total per plot of 144 plants (12 of each of 12 species) separated by $2 \mathrm{~m}$ from each other (Fig. 1). Twelve species in 16 planted plots were spaced to maximize distance between conspecifics within each subplot. Growing vegetation within $50 \mathrm{~cm}$ of planted seedlings was removed monthly until the sapling was taller than surrounding grass (to $1.5 \mathrm{~m}$ high). The matrix between fenced plots remained short, closely cropped grass in active pastures that were maintained as part of the experimental design. Cattle consumed seedlings and kept grasses cropped up to $1 \mathrm{~m}$ inside fences.

Plots differed in distance to forest. Plot midpoints were $90-480 \mathrm{~m}$ from 30-40-year-old secondary forest $(241 \pm 18 \mathrm{~m}$ [mean $\pm \mathrm{SE}])$ to the south and southeast of the grid, and $236-409 \mathrm{~m}$ from privately owned primary forest to the east $(324 \pm 12 \mathrm{~m})$. Taller old-growth forest of the Los Tuxtlas Biological Station was $344-800 \mathrm{~m}$ $(568 \pm 31 \mathrm{~m})$ to the south of plots.

Woody seedlings $>10 \mathrm{~cm}$ high, excluding planted individuals, were counted in each fenced plot every four months from 20 through 60 months after cattle exclusion. Recruited species were identified, tagged, and measured (height and basal diameter, with diameter at breast height and canopy width for growing trees). Re-sprouts of pre-existing trees $(0-3$ per plot) were cut. These were not counted in censuses. Nomenclature followed Ibarra-Manriquez and Sinaca $(1995,1996 a, b$; see Appendices A and B).

\section{Statistical analyses}

The basic tool of the following analyses is repeatedmeasures ANOVA. We use a factorial design in which 
samples of recruits are measured every four months, where the number of months since cattle exclusion is the repeated factor. Dependent variables are species recruitment rate for the first repeated-measures ANOVA, recruitment rate regardless of species for the second (hereafter "individual recruitment"). The repeatedmeasures ANOVAs included planting treatment with three levels (plots planted with animal-dispersed species, planted with wind-dispersed species, and unplanted controls); life history with two levels (pioneer and later-successional recruits); and dispersal mode with two levels (recruits from seeds dispersed by animals or wind). We evaluated overall significance levels for repeated measures using the Greenhouse-Geisser correction for sphericity. Means are accompanied by standard deviations unless otherwise indicated.

Statistical analyses were performed using STATISTICA 7.0 (StatSoft, Tulsa, Oklahoma, USA) and SYSTAT 13 (Chicago, Illinois, USA). Derivative estimates and metrics addressing community structure (projected richness, alpha and beta diversities, multidimensional scaling, and similarity indices) will be developed elsewhere.

\section{RESULTS \\ Overview}

During 60 months of cattle exclosure, 44 woody species from 27 families recruited in a density of 0.057 individuals $/ \mathrm{m}^{2}$ (Appendix B). Overall survival of recruits was $81 \%$ after 60 months of cattle exclosure. Common families included Melastomataceae, Euphorbiaceae, and Piperaceae, with four, four, and three species, respectively. Bursera simaruba (Burseraceae), a later-successional animal-dispersed tree that is widely used as a shade tree and in living fences, had the highest density (0.017 individuals $\left./ \mathrm{m}^{2}\right)$. Cordia alliodora (Boraginaceae), a pioneer species dispersed by wind, and Conostegia xalapensis (Melastomataceae), a pioneer animal-dispersed shrub, were the second and third most important species by density $\left(0.008\right.$ and 0.004 individuals $/ \mathrm{m}^{2}$, respectively). Fifty-six percent of the recruited seedlings were pioneers, $67 \%$ of which were of animal-dispersed taxa. The remaining $44 \%$ of the seedlings were latersuccessionals, of which $87 \%$ were animal dispersed and $13 \%$ wind dispersed.

Between 20 and 60 months since cattle exclusion, repeated-measures ANOVA indicated increases in recruitment of species and individuals. Species recruitment rate increased significantly over time in a roughly linear fashion $\left(F_{10,840}=51.11, P<0.00001\right.$; Fig. 2a). Individual recruitment also increased, with apparent acceleration between 44 and 60 months (repeatedmeasures $F_{10}, 840=21.72, P<0.00001$; Fig. $2 b$ ). Of most interest were within-subject interactions of main effects with time.

\section{Interactions with time}

Interactions of time and response variables were evident. Interaction between time and planting treat-
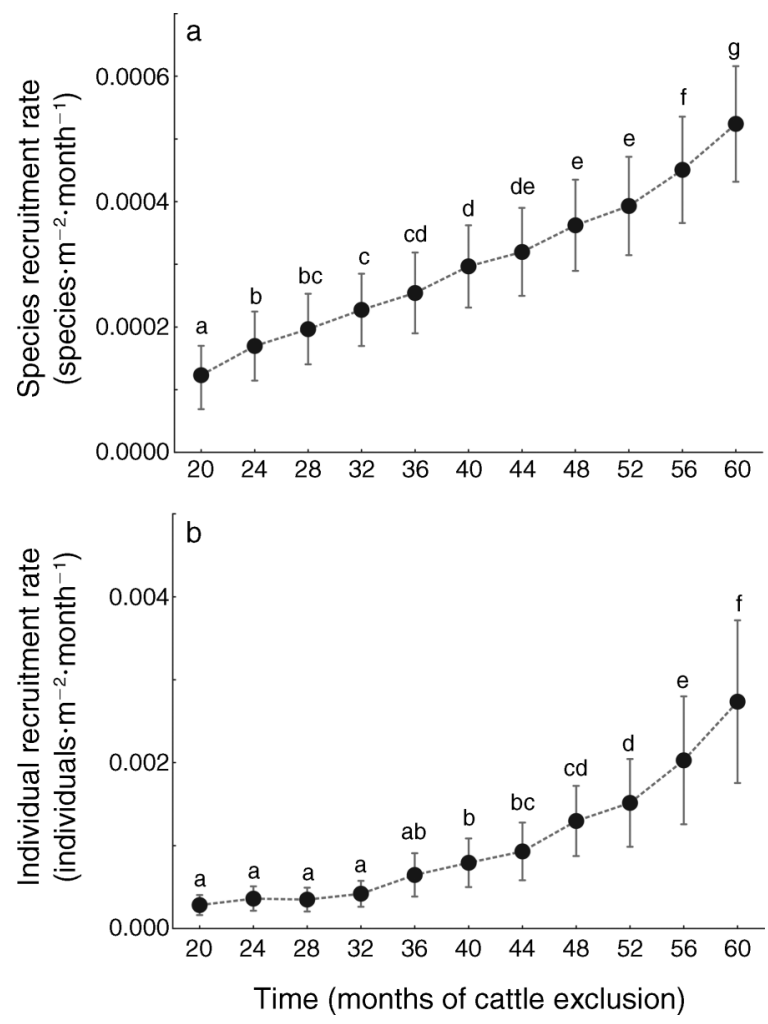

FIG. 2. Species and individual recruitment rates through 60 months of cattle exclusion (through June 2011) for (a) species and (b) individuals. Shown are means with $95 \%$ confidence intervals. Note differences in scales of $y$-axes. Different letters indicate significant differences between time periods based on post-hoc Tukey tests at $P<0.05$.

ments from 20 through 60 months showed significantly higher recruitment rates in planted vs. control plots for species (repeated-measures $F_{20,840}=2.54, P=0.0002$; Fig. 3a) and individuals $\left(F_{20,840}=3.33, P<0.0001\right.$; Fig. $3 b)$. Interaction of time and life history showed a significantly higher increase of pioneer species recruitment rate as compared with later-successional species (repeated-measures $F_{10,840}=11.43, P<0.0001$; Fig. 4a). Individual recruitment rates did not differ by life histories $\left(F_{10}, 840=0.95, P=0.49\right.$; Fig. $\left.4 \mathrm{~b}\right)$. Interaction of time and dispersal mode indicated a larger increase in recruitment rates of animal-dispersed compared to wind-dispersed species (Fig. 4c; repeated measures $F_{10}$, $840=7.44, P<0.0001)$. Individual recruitment rates also differed between animal- and wind-dispersed trees and shrubs over time (Fig. $4 \mathrm{~d} ; F_{10}, 840=1.84, P=0.05$ ).

Interactions between treatments, life history, dispersal mode, and time showed wide differences in individual recruitment rates (Fig. 5; repeated-measures $F_{20,840}=$ 2.06, $P=0.004)$. Pioneer recruits did not differ among planting treatments (Figs. 5a and b). Later-successional animal-dispersed recruits increased in planted plots, but not in controls (Fig. 5c; $F_{20,210}=3.09, P=0.00002$ ). Later-successional wind-dispersed recruits did not 

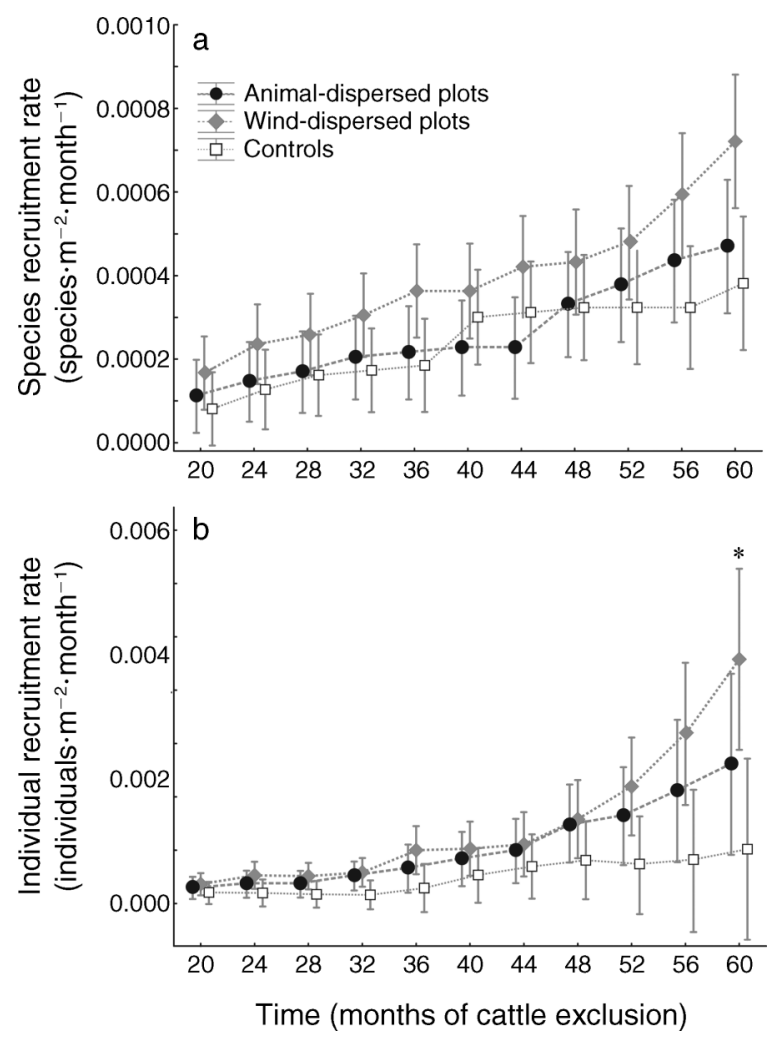

FIG. 3. Species and individual recruitment rates by planting treatment. Means are represented by circles (animal-dispersed plantings), squares (wind-dispersed plantings), and diamonds (controls). Error bars indicate 95\% confidence intervals. Asterisk indicates that wind-dispersed plots show higher individual recruitment rate than controls at 60 months (Tukey test, $P \leq 0.05)$.

change with planting treatments over time (Fig. 5d). High recruitment rates of later-successional individuals of species dispersed by animals (Fig. 5c) in plots of winddispersed trees was influenced by a precocious plot of greater soil depth (mean $42.5 \mathrm{~cm}$ ) than other planted plots $\left(21.5 \pm 2.5 \mathrm{~cm} ; \log _{10}\right.$-transformed to meet conditions of normality, $\left.t_{14}=-7.3, P=0.00001\right)$ that formed a closed canopy at 40 months. With this outlier excluded, recruitment in stands of wind- and animaldispersed trees were indistinguishable. Pooled planting treatments also differed from controls $\left(F_{10,210}=3.68, P\right.$ $=0.00015)$.

\section{DisCUSSION}

Restoration of tropical biodiversity in abandoned pastures requires recruitment of trees from surrounding forests and forest fragments. This is true whether abandoned land is released to natural secondary succession, whether monocultures of planted trees provide conditions necessary for establishment of shade-tolerant seedlings, or whether mixed-species stands of planted trees do the same with added heterogeneity of community structure (e.g., see Aide et al. 1995, Chazdon 2003, Butler et al. 2008). In diverse tropical landscapes, the potential advantages of planted mixed-species stands are heterogeneity of conditions for seedling establishment in addition to heterogeneity of cover and resources for potential dispersal agents. Here we test for differences in recruitment of forest tree species by successional status and dispersal mode in fenced mixed-species plantings of animal- or winddispersed trees and unplanted exclosures that simulate natural succession.

\section{Characterizing the recruited community}

Most tropical rain forest species do not arrive or survive in recently abandoned pastures. A common pattern is that pioneer trees with minute seeds carried by turbulent winds colonize open areas after abandonment, establishing low-diversity communities that potentially last years to decades (Janzen 1988, Zimmerman et al. 2000, Ingle 2003, Martínez-Garza and Howe 2003; see Bohrer et al. 2008). Consistent with this generalization, initial seed fall and numerical recruitment at Los Tuxtlas are heavily skewed toward wind-dispersed pioneers that establish haphazardly over the landscape or arrive but do not establish at all (Martínez-Garza et al. 2009, Howe et al. 2010). We expect that future wind-dispersed recruits will be pioneers or seedlings of planted latersuccessional trees, while animal-dispersed recruits will represent both planted species and increasing richness of immigrant species from nearby forest.

Challenges to restoration of biodiversity in abandoned pastures at Los Tuxtlas include seed and recruitment limitation of animal-dispersed trees from nearby forest remnants. Approximately $76 \%$ of rainforest tree species at Los Tuxtlas are dispersed by animals (Ibarra-Manriquez and Oyama 1992). Over time one expects this majority of animal-dispersed taxa to increase because there are many more of them than wind-dispersed species. Biotically dispersed seeds carried by wide-ranging bats or birds are more mobile than any but the smallest abiotically dispersed seeds of primaryforest trees. Relevant issues for a given site are availability of seed sources of primary and old secondary forest, and how quickly rates of seed fall and particularly seedling recruitment change after pastures are abandoned.

Xeric pasture conditions and dispersal limitation pose serious impediments to restoration of tropical diversity on fallow land. High temperatures, direct solar radiation, low humidity, and little leaf litter preclude germination and establishment of many later-successional trees (Parrotta et al. 1997). Some of these do well in xeric pasture conditions if they are planted as seedlings (Martínez-Garza et al. 2005), but many do not establish from seed unless they arrive in scarce sites with enough shade and moisture to allow germination and establishment without competition from dense grasses (Otero-Arnáiz et al. 1999). Sixty months after cattle exclusion, $\sim 15 \%$ of 300 local woody species are 

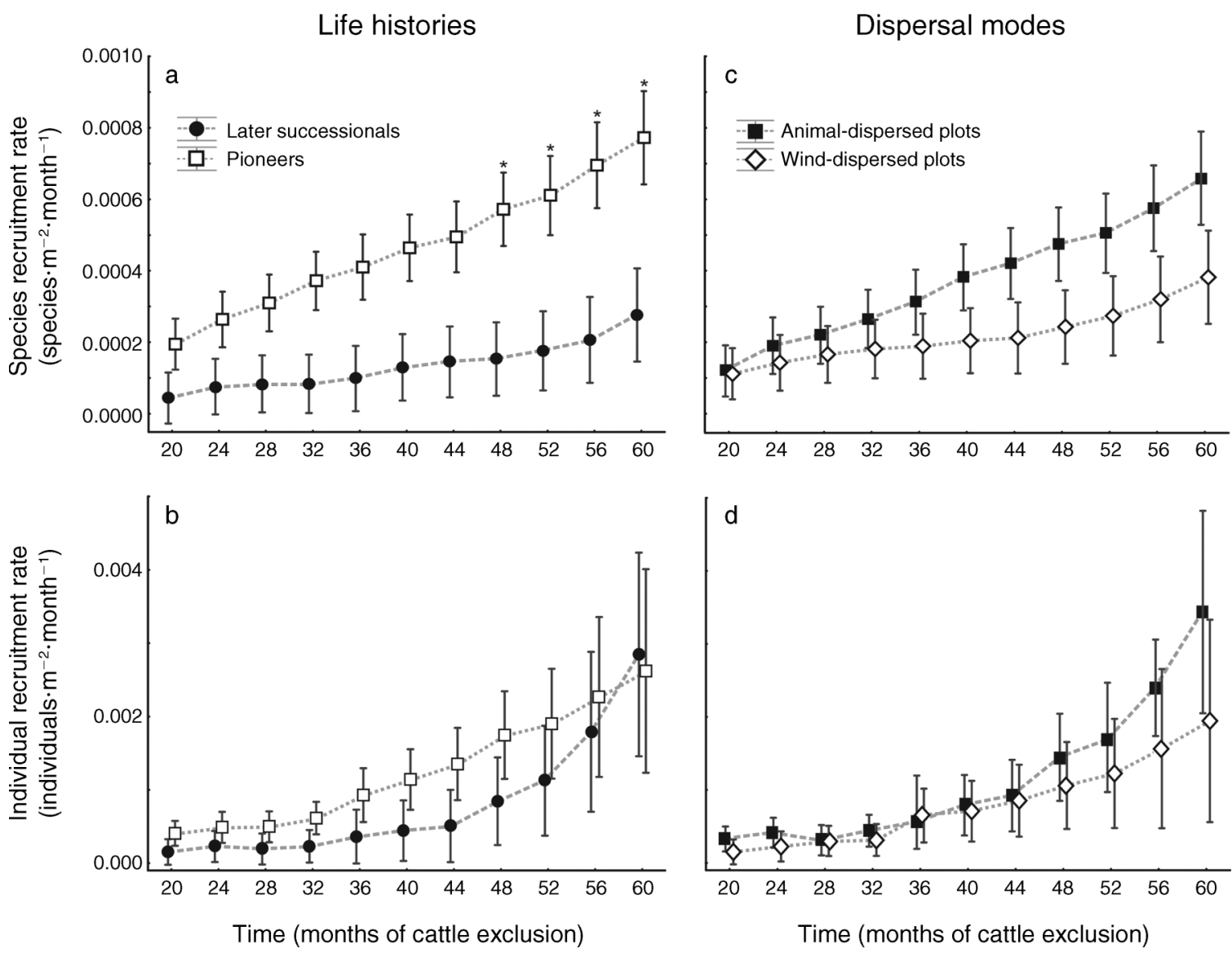

FIG. 4. Species recruitment and individual recruitment rates for tree seedlings of (a, b) pioneer and later-successional species and (c, d) animal- or wind-dispersed species. Error bars indicate $95 \%$ confidence intervals.

established in at least one of the three treatments. Low input of seeds and poor establishment of later-successional species explain this lag. Of most interest in our study, accelerating accumulation of animal-dispersed species of secondary and primary forest is evident in planted plots 48 months after cattle exclusion, but not in control plots. This likely reflects improving conditions for shade-tolerant seedlings arriving from forest 90-480 $\mathrm{m}$ away, and quite likely increasing attractiveness of planted plots to fruit-eating birds and mammals.

\section{Recruitment in pastures and managed plantations}

The effectiveness of seed dispersal from the plant perspective depends on where seeds land (Schupp et al. 2010). Mature tree plantations in agricultural landscapes accelerate seedling recruitment and ecological succession (Kuusipalo et al. 1995, Lugo 1997, Parrotta et al. 1997, Powers et al. 1997, Keenan et al. 1999, Chazdon 2008). In general, recruitment of woody plants into recently abandoned pastures is substantially lower than into monospecific or mixed stands of planted trees that offer shade to seedlings and cover to dispersal agents. In 1516-year-old successional plots established on abandoned Costa Rican pastures, for instance, natural recruitment of woody species is about half that into monospecific stands of three species, or into mixed stands of the same three species (Butler et al. 2008). Even with a clear general result, individual recruitment under some monocultures overlaps with unplanted controls, indicating the need to further clarify interactions between planted tree composition, dispersal, and recruitment.

Landscape features that attract animal dispersers into pastures play a critical role in regeneration of tropical forest (Nepstad et al. 1996, Wunderle 1997, MartínezGarza and Howe 2003). For example, seed densities of heterospecifics in exclosures under isolated remnant trees in pastures can be as high as in the understory of continuous forest (Laborde et al. 2008). Moreover, species matter. Seedling recruitment in enclosures around isolated pasture trees is higher under sparse canopies, whether fruits are fleshy or dry (Slocum 2001). Once cattle are excluded from pastures, remnant trees become regeneration nuclei from which vegetation spreads (Holl et al. 2010). For pioneer trees, the reproductive niche of large adults is often in vegetation too dense to allow establishment of their own offspring, indicating an ontological niche shift between seedling and adult requirements (see Miriti 2006). For instance, 


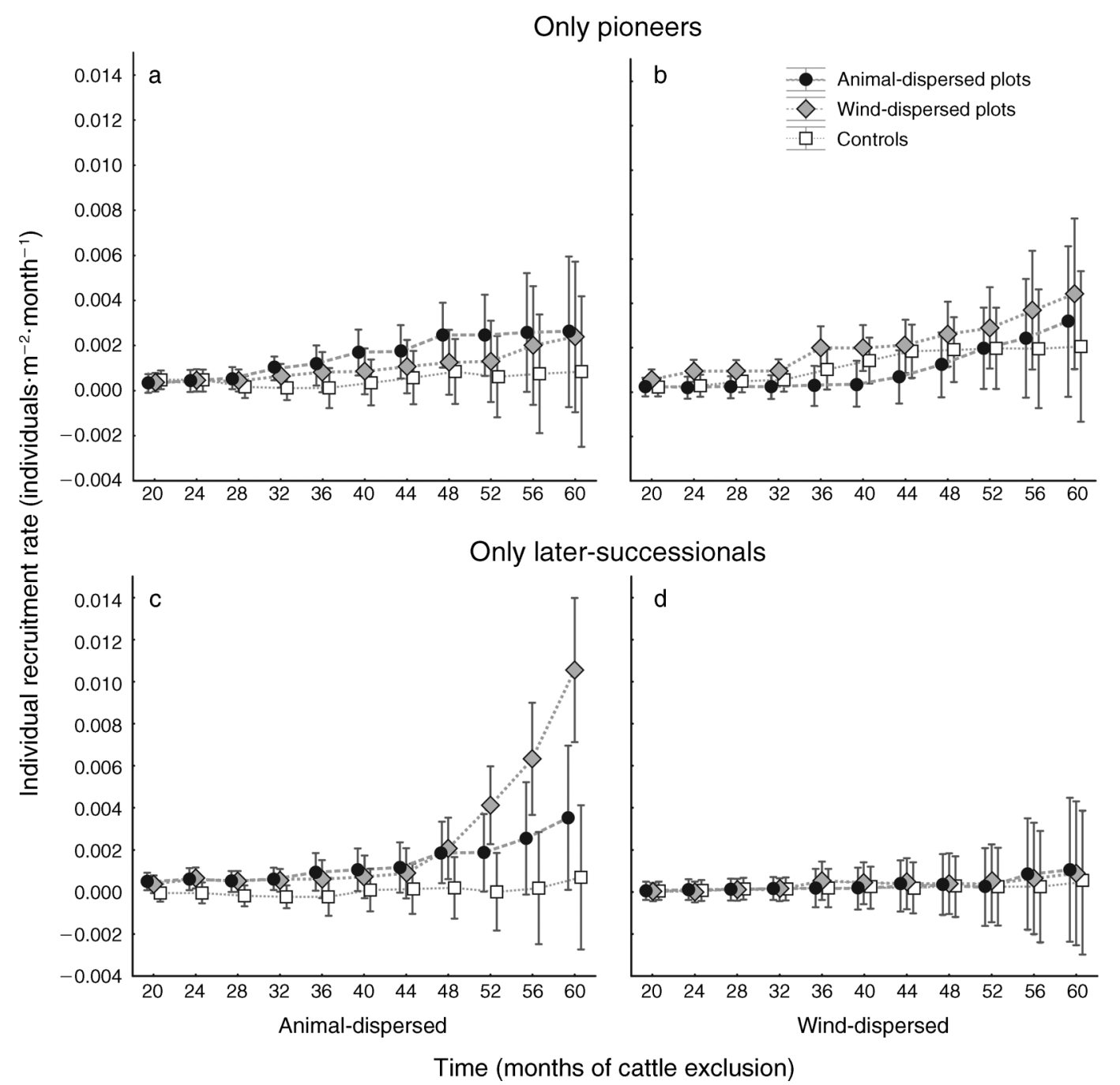

FIG. 5. Individual recruitment rates of pioneer and later-successional trees and shrubs in three planting treatments. Means are represented by circles (animal-dispersed plantings), squares (wind-dispersed plantings), and diamonds (control plots). Error bars indicate $95 \%$ confidence intervals.

large Miconia prasina adults in Puerto Rico recruit far more seeds in open habitats than under their own canopies (Pascarella et al. 2007). Fenced plantings that attract fruit-eating animals potentially act as buffers around or stepping stones between forest remnants for recruitment of shade-tolerant seedlings, ultimately facilitating pollen and seed exchange among forest fragments and isolated tree stands.

In the present experiment, plots remained grass covered for nearly a year following re-planting after a severe dry-season drought in 2007 killed most seedlings planted in 2006 (Martínez-Garza et al. 2011). Accordingly, cattle exclusion was the single most important factor contributing to increase of recruitment rates during the first 20 months, with substantial changes in soil and litter characteristics under a mantle of grass (Tobón et al. 2011, Roa-Fuentes et al. 2013). After 20 months, planted stands and recruits from natural dispersal grew without interruption.

After 20 months, species recruitment rates increased steadily, with individual and species recruitment rates increasing much faster in planted stands than in controls. Most important was colonization of planted stands by later-successional trees dispersed by animals. Perches alone, without leaves or food resources, elevate seed fall of some bird-dispersed shrub and tree species, but do not necessarily elevate seedling recruitment (Holl 1998). By contrast, in our experiment individual recruitment of later-successional species accelerates steadily after 48 months following cattle exclusion in planted plots, but not in controls. A few planted animaldispersed Cecropia obtusifolia and Ficus yoponensis and wind-dispersed Heliocarpus appendiculatus, Platymiscum pinnatum, and Vochysia guatemalensis reached reproductive maturity between 48 and 60 months after cattle 
exclusion. Nonetheless, most individual seedling recruits $(96 \%)$ were not of experimental species. Of those that were, most individuals of $C$. obtusifolia established before planted trees bore fruit. After 20 months, plantings provided resting sites, cover, and foraging sites for birds that eat both insects and fruits, and eventually provided both fruit resources for bats and birds that import seeds and environmental conditions that allowed shade-tolerant colonists from nearby forests to establish.

\section{Plant dynamics in an agricultural mosaic}

Seeds must be present for recruitment to occur, but patterns of seedling recruitment often do not closely reflect patterns of seed fall. At least 30 years of intense grazing pressure have left Los Tuxtlas pastures with little litter over thin, eroded soils (Tobón et al. 2011). In tropical soils, few woody species other than pioneers are capable of long-term seed dormancy (Dalling and Denslow 1997, Norden et al. 2009). Emerging seedlings from seed banks at our Los Tuxtlas site are primarily those of animal-dispersed trees left as legacies around stumps of figs (Ficus spp.) and Bursera simaruba that were cut during site preparation (Howe et al. 2010). Virtually all recruits (96\%) of trees during the first 60 months after cattle exclusion resulted from seed dispersal at least $90-480 \mathrm{~m}$ from seed sources in forests or from isolated shade trees in pastures.

A simple distinction between animal- and winddispersed species gives insufficient weight to complexities in both dispersal modes. Wind-dispersed species, $24 \%$ of tree species in the region, have a variety of dispersal strategies (see Wright et al. 2008). Initial colonization in the Los Tuxtlas plots has been by long-distance dispersal of species with small $(<0.05 \mathrm{~g})$, widely disseminated seeds of pioneers (e.g., Cordia alliodora, Eupatorium galeotti, Heliocarpus appendiculatus, H. donnell-smithii). Occasionally colonization of open ground is dominated by later-successional wind-dispersed trees with small seeds (e.g., Tabebuia heterophylla with $10-\mathrm{mg}$ seeds in highland Puerto Rico; Zimmerman et al. 2000), but that is not the pattern at Los Tuxtlas. Aside from Albizia purpusii, a legacy species cut during site preparation (Howe et al. 2010), later-successional trees dispersed by wind are a negligible presence. We expect this dearth of recruitment of later-successional trees dispersed by wind to continue, other than by the eight species that we experimentally establish.

Animal behavior mediates dissemination of animaldispersed plants. Forest birds and mammals differ in proclivity to cross open ground. Some move easily along edges, but hesitate to cross alien matrices (e.g., Levey et al. 2005); in the Los Tuxtlas landscape about $40 \%$ of 257 species of birds and mammals leave forest rarely, if at all (Estrada et al. 1993). Of the remaining 60\%, many fruiteating birds and bats live in the fragmented landscape and both distribute seeds of pioneers within the agricultural mosaic and bring seeds from forest trees into pastures
(Guevara and Laborde 1993, Galindo-Gonzalez et al. 2000). Common visitors to our plots, including large bats (Artibeus jamaicensis) and birds (Ramphastos sulfuratus), travel hundreds of meters to preferred fruiting trees (Handley et al. 1991, Graham 2001). Such long-distance commuters are most likely to bring seeds of forest trees. In 60 months of cattle exclusion, recruitment of latersuccessional trees shows no sign of an asymptote; quite the contrary, species recruitment is increasing and individual recruitment is accelerating.

Recruitment patterns underscore differences among ecosystems. In early secondary growth in temperate South Carolina, richness of wind-dispersed plants increases over seven years, while animal-dispersed species asymptote in five years (Damschen et al. 2008). In our study of tropical trees, dispersal limitation of later-successional trees dispersed by wind is the rule, excepting trees that we plant (Martínez-Garza and González-Montagut 1999, Martínez-Garza et al. 2009). At Los Tuxtlas, with $\sim 100$ species of fruit-eating birds and mammals and 230 species of animal-dispersed trees of old secondary and primary forest, recruitment of new species into experimental plots will continue to increase until priority effects of shade-tolerant saplings and adults suppresses newcomers (Hubbell et al. 1999). The present rate of recruitment of later-successional animaldispersed tree seedlings remains less than one per square meter per month, with no sign of leveling off.

\section{Future composition}

Stands of trees in agricultural mosaics have the potential to increase or maintain diversity of animaldispersed plants and fruit-eating animals that would otherwise be lost. Such habitat patches additionally may provide pollen and seed exchange among forest remnants (see Turner and Corlett 1996, Hughes et al. 2002, Kramer et al. 2008). Seeds of forest trees species will arrive, carried by birds and bats that commute from forest to feeding sites. The flora and fauna of small habitat patches will be subsets of those in continuous forest (Cordeiro et al. 2009), but at Los Tuxtlas they will be large subsets (Estrada et al. 1993, Arroyo-Rodríguez et al. 2008). Effective dispersal agents of seeds of forest trees into synthetic plant communities will be commuters from forest that fly substantial distances to and from habitat patches in which they forage, and they already appear to be bringing seeds of species that do not arrive in grassy control plots.

A caveat is that the future patterns of seed or seedling mortality within synthetic habitat patches are not yet knowable. There is no indication of density-dependent mortality among conspecific immigrant seedlings, nor is there yet evidence of density-dependent mortality across species from generalized seed or seedling predators (Howe and Smallwood 1982, Kwit et al. 2004). To date, seedling densities remain low, and what mortality occurs is likely density independent. As planted trees begin to produce large fruit crops, negative density-dependent 
mortality of seeds and seedlings is certain to increase (Harms et al. 2000, Alvarez-Loayza and Terborgh 2011). The much larger pool of forest tree species likely to colonize our plots relative to planted species is likely to increase recruitment success well before density dependence occurs. Under this scenario we expect species accumulation to increase in stands of animaldispersed trees that serve as magnets for bird and bat dispersal agents more than in stands of wind-dispersed trees that offer little food.

\section{Conclusion}

Sparse plantings of rapidly growing trees will have different values in different circumstances. Plantings of pioneer trees on abandoned land far from seed sources may stabilize soil, but will probably be insufficient to attract any but the most mobile fruit-eating birds and bats. Enrichment with trees bearing fruits valued by long-distance commuters, such as figs (Ficus insipida or F. yoponensis) known to large bats (Artibeus jamaicensis) hundreds to thousands of meters from forest, could accelerate an otherwise very slow process in planted forest stands far from seed sources.

Conversely, it is useful to ask where assisted succession is a good idea (Holl and Aide 2011). Abandoned land on deep soils near forest seed sources may well recover quickly without assistance if dispersal agents are common in the landscape. If land is abandoned or may be acquired on such sites, unassisted succession may be cost-effective. A different solution applies to land perceived as too valuable to abandon, which is the case at Los Tuxtlas. In permanent agricultural mosaics, stepping-stone forest patches could serve an important function in maintaining "countryside diversity" of both plants and animals (Turner and Corlett 1996, Daily et al. 2001, Hughes et al. 2002), while preserving a degree of connectivity during a period of historically rapid climate change (Corlett 2011). On our site, unassisted succession is slow; planted trees that grow rapidly are likely to increase recruitment of animal-dispersed trees of old secondary and primary forest, ultimately providing stands of young adult trees of many species that provide food for fruit-eating animals, mates through long-distance pollination for widely dispersed "populations" of trees (Kramer et al. 2008), and seed exchange among small forest fragments and larger remnants. Stepping-stone patches, more widely spaced than our experimental design permits, may serve a critical purpose in maintaining connectivity among forest fragments and maintaining biodiversity in highly altered landscapes.

\section{ACKNOWLEDGMENTS}

We are grateful to R. Coates and Alvaro Campos for institutional support and to E. Velasco, Luz María Ayestarán, Flavio Márquez, and the Martínez-Garza lab group for field assistance. We are grateful to the Howe lab group and $\mathrm{R}$. Chazdon, M. Martínez-Ramos, J. A. Meave del Castillo, B. Ferguson, J. Benítez-Malvido, M. Gonzalez-Meler, E. Minor, and C. Vriesendorp for constructive comments. We also thank the Graduate Program in Biological Sciences of the National Autonomous University of Mexico (UNAM) and the scholarship and financial support provided by the National Council of Science and Technology (CONACyT) and UNAM. Financial and logistical support from the University of Illinois, Universidad Autónoma del Estado de Morelos, Universidad Nacional Autónoma de México, and the National Science Foundation (DEB 0516259) made the study possible.

\section{Literature Cited}

Aide, T. M., J. K. Zimmerman, L. Herrera, M. Rosario, and M. Serrano. 1995. Forest recovery in abandoned tropical pastures in Puerto-Rico. Forest Ecology and Management 77:77-86.

Alvarez-Loayza, P., and J. Terborgh. 2011. Fates of seedling carpets in an Amazonian floodplain forest: intra-cohort competition or attack by enemies? Journal of Ecology 99:1045-1054.

Arroyo-Rodríguez, V., E. Pineda, F. Escobar, and J. BenítezMalvido. 2008. Value of small patches in the conservation of plant-species diversity in highly fragmented rainforest. Conservation Biology 23:729-739.

Benítez-Malvido, J., and A. Lemus-Albor. 2005. The seedling community of tropical rain forest edges and its interaction with herbivores and pathogens. Biotropica 37:301-313.

Bohrer, G., G. G. Katul, R. Nathan, R. L. Walko, and R. Avissar. 2008. Effects of canopy heterogeneity, seed abscission and inertia on wind-driven dispersal kernels of tree seeds. Journal of Ecology 96:569-580.

Bryant, D., D. Nielsen, and L. Tangley. 1997. The last frontier forests: ecosystems and economies on the edge. World Resources Institute, Washington, D.C., USA.

Butler, R., F. Montagnini, and P. Arroyo. 2008. Woody understory plant diversity in pure and mixed native tree plantations at La Selva Biological Station, Costa Rica. Forest Ecology and Management 255:2251-2263.

Chazdon, R. L. 2003. Tropical forest recovery: legacies of human impact and natural disturbances. Perspectives in Plant Ecology, Evolution and Systematics 6:51-71.

Chazdon, R. L. 2008. Beyond deforestation: restoring forests and ecosystem services on degraded lands. Science 320:14581460.

Chazdon, R. L., A. Chao, R. K. Colwell, S.-Y. Lin, N. Norden, S. G. Letcher, D. B. Clark, B. Finegan, and J. P. Arroyo. 2011. A novel statistical method for classifying habitat generalists and specialists. Ecology 92:1332-1343.

Cordeiro, N. J., H. J. Ndangalasi, J. P. McEntee, and H. F. Howe. 2009. Disperser limitation and recruitment of an endemic African tree in a fragmented landscape. Ecology 90:1030-1041.

Corlett, R. T. 2011. Impacts of warming on tropical lowland rainforests. Trends in Ecology and Evolution 26:606-613.

Daily, G. C., P. R. Ehrlich, and G. A. Sánchez-Azofeifa. 2001. Countryside biogeography: use of human-dominated habitats by the avifauna of Southern Costa Rica. Ecological Applications 11:1-13.

Dalling, J. W., and J. S. Denslow. 1997. Soil seed bank composition along a forest chronosequence in seasonally moist tropical forest, Panama. Journal of Vegetation Science 9:669-678.

Damschen, E. I., L. A. Brudvig, N. M. Haddad, D. J. Levey, J. L. Orrock, and J. J. Tewksbury. 2008. The movement ecology and dynamics of plant communities in fragmented landscapes. Proceedings of the National Academy of Sciences USA 105:19078-19083.

Dirzo, R. 2001. Tropical forests. Pages 251-276 in O. Sala, F. S. Chapin, and E. Huber-Sannwald, editors. Global biodiversity in a changing environment. Springer-Verlag, New York, New York, USA. 
Dirzo, R., E. González Soriano, and C. R. Vogt. 1997. La región de Los Tuxtlas: introducción general. Pages 3-6 in E. González-Soriano, R. Dirzo, and R. C. Vogt, editors. Historia natural de Los Tuxtlas. Universidad Nacional Autónoma de México. Instituto de Biología, D.F., México.

Estrada, A., and R. Coates-Estrada. 2001. Species composition and reproductive phenology of bats in a tropical landscape at Los Tuxtlas, Mexico. Journal of Tropical Ecology 17:627664.

Estrada, A., and R. Coates-Estrada. 2005. Diversity of Neotropical migratory landbird species assemblages in forest fragments and man-made vegetation in Los Tuxtlas, Mexico. Biodiversity and Conservation 14:1719-1734.

Estrada, A., R. Coates-Estrada, and D. Meritt. 1993. Bat species richness and abundance in tropical rain forest fragments and in agricultural habitats at Los Tuxtlas, Mexico. Ecography 16:309-318.

Fahrig, L. 2003. Effects of habitat fragmentation on biodiversity. Annual Review of Ecology, Evolution, and Systematics 34:487-515.

Fearnside, P. M. 2005. Deforestation in Brazilian Amazonia: history, rates, and consequences. Conservation Biology 19:680-688.

Frankie, G. W., H. G. Baker, and P. A. Opler. 1974. Comparative phenological studies of trees in tropical wet and dry forests in the lowlands of Costa Rica. Journal of Ecology 62:881-919.

Galindo-Gonzalez, J., S. Guevara, and V. J. Sosa. 2000. Bat- and bird-generated seed rains at isolated trees in pastures in a tropical rainforest. Conservation Biology 14:1693-1703.

Graham, C. H. 2001. Factors influencing movement patterns of keel-billed toucans in a fragmented tropical landscape in southern Mexico. Conservation Biology 15:1789-1798.

Guevara, S., and J. Laborde. 1993. Monitoring seed dispersal at isolated standing trees in tropical pastures: consequences for local species availability. Vegetatio 107/108:319-338.

Guevara, S., J. Laborde, and G. Sánchez-Ríos. 2004. Los Tuxtlas. El paisaje de la sierra. Instituto de Ecología, A.C., Xalapa, Veracruz, Mexico.

Handley, C. O., A. L. Gardner, and D. E. Wilson. 1991. Movements, demography and natural history of the common fruit bat, Artibeus jamaicensis, on Barro Colorado Island, Panama. Smithsonian Institution Press, Washington, D.C., USA.

Harms, K. E., S. J. Wright, O. Calderon, A. Hernandez, and E. A. Herre. 2000. Pervasive density-dependent recruitment enhances seedling diversity in a tropical forest. Nature 404:493-495.

Holl, K. D. 1998. Do bird perching structures elevate seed rain and seedling establishment in abandoned tropical pasture? Restoration Ecology 6:253-261.

Holl, K. D., and T. M. Aide. 2011. When and where to actively restore ecosystems? Forest Ecology and Management 261:1558-1563.

Holl, K. D., R. A. Zahawi, R. J. Cole, R. Ostertag, and S. Cordell. 2010. Planting seedlings in tree islands versus plantations as a large-scale tropical forest restoration strategy. Restoration Ecology 19:470-479.

Houghton, R. A. 1994. The worldwide extent of land-use change. BioScience 44:305-313.

Howe, H. F., and J. Smallwood. 1982. Ecology of seed dispersal. Annual Review of Ecology and Systematics $13: 201-228$.

Howe, H. F., Y. Urincho-Pantaleon, M. de la Pena-Domene, and C. Martínez-Garza. 2010. Early seed fall and seedling emergence: precursors to tropical restoration. Oecologia 164:731-740.

Hubbell, S. P., R. B. Foster, S. T. O'Brien, K. E. Harms, R. Condit, B. Wechsler, S. J. Wright, and S. L. de Lao. 1999.
Light-gap disturbances, recruitment limitation, and tree diversity in a neotropical forest. Science 283:554-557.

Hughes, J. B., G. C. Daily, and P. R. Ehrlich. 2002. Conservation of tropical forest birds in countryside habitats. Ecology Letters 5:121-129.

Ibarra-Manriquez, G., and K. Oyama. 1992. Ecological correlates of reproductive traits of Mexican rain-forest trees. American Journal of Botany 79:383-394.

Ibarra-Manriquez, G., and S. Sinaca. 1995. Lista floristica comentada de la Estación de Biología Tropical "Los Tuxtlas", Veracruz, México. Revista de Biologia Tropical 43:75-115.

Ibarra-Manriquez, G., and S. Sinaca. 1996a. Lista floristica comentada de la Estación de Biología Tropical "Los Tuxtlas", Veracruz, México (Mimosaceae a Verbenaceae). Revista de Biologia Tropical 44:41-60.

Ibarra-Manriquez, G., and S. Sinaca. 1996b. Lista floristica comentada de la Estación de Biología Tropical "Los Tuxtlas", Veracruz, México (Violaceae a Zingiberaceae). Revista de Biologia Tropical 44:427-447.

Ingle, N. R. 2003. Seed dispersal by wind, birds, and bats between Philippine montane rainforest and successional vegetation. Oecologia 134:251-261.

Janzen, D. H. 1988. Management of habitat fragments in a tropical dry forest: growth. Annals of the Missouri Botanical Garden 75:105-116.

Jones, F. A., C. J. Peterson, and B. L. Haines. 2003. Seed predation in neotropical pre-montane pastures: site, distance, and species effects. Biotropica 35:219-225.

Keenan, R. J., D. Lamb, J. Parrotta, and J. Kikkawa. 1999. Ecosystem management in tropical timber plantations: satisfying economic, conservation, and social objectives. Journal of Sustainable Forestry 9:117-134.

Kramer, A. T., J. L. Ison, M. V. Ashley, and H. F. Howe. 2008. The paradox of forest fragmentation genetics. Conservation Biology 22:878-885.

Kuusipalo, J., G. Ådjers, Y. Jafarsidik, A. Otsamo, K. Tuomela, and R. Vuokko. 1995. Restoration of natural vegetation in degraded Imperata cylindrica grassland: understorey development in forest plantations. Journal of Vegetation Science 6:205-210.

Kwit, C., D. J. Levey, and C. H. Greenberg. 2004. Contagious seed dispersal beneath heterospecific fruiting trees and its consequences. Oikos 107:303-308.

Laborde, J., S. Guevara, and G. Sanchez-Rios. 2008. Tree and shrub seed dispersal in pastures: the importance of rainforest trees outside forest fragments. EcoScience 15:6-16.

Levey, D. J., B. M. Bolker, J. J. Tewksbury, S. Sargent, and N. M. Haddad. 2005. Effects of landscape corridors on seed dispersal by birds. Science 309:146-148.

Lugo, A. E. 1997. The apparent paradox of reestablishing species richness on degraded lands with tree monocultures. Forest Ecology and Management 99:9-19.

Martínez-Garza, C., A. Flores-Palacios, M. De La PeñaDomene, and H. F. Howe. 2009. Seed rain in a tropical agricultural landscape. Journal of Tropical Ecology 25:541550 .

Martínez-Garza, C., and R. González-Montagut. 1999. Seed rain from forest fragments into tropical pastures in Los Tuxtlas, Mexico. Plant Ecology 145:255-265.

Martínez-Garza, C., and H. F. Howe. 2003. Restoring tropical diversity: beating the time tax on species loss. Journal of Applied Ecology 40:423-429.

Martínez-Garza, C., V. Pena, M. Ricker, A. Campos, and H. F. Howe. 2005. Restoring tropical biodiversity: leaf traits predict growth and survival of late-successional trees in early-successional environments. Forest Ecology and Management 217:365-379.

Martínez-Garza, C., W. Tobón, J. Campo, and H. F. Howe. 2011. Drought mortality of tree seedlings in an eroded 
tropical pasture. Land Degradation and Development. dx. doi.org/10.1002/ldr.1127

Martínez-Ramos, M. 1985. Claros, ciclos vitales de los árboles tropicales y la regeneración natural de las selvas altas perennifolias. Pages 191-239 in A. Gómez-Pompa and S. del Amo, editors. Investigaciones sobre la Regeneración de las Selvas Altas en Veracruz, México. Editorial Alhambra Mexicana, Ciudad de México, D.F., Mexico.

Miriti, M. N. 2006. Ontogenetic shift from facilitation to competition in a desert shrub. Journal of Ecology 94:973979.

Myster, R. W. 2004. Post-agricultural invasion, establishment, and growth of neotropical trees. Botanical Review 70:381402.

Nepstad, D. C., C. Uhl, C. A. Pereira, and J. M. C. da Silva. 1996. A comparative study of tree establishment in abandoned pasture and mature forest of eastern Amazonia. Oikos 76:25-39.

Nepstad, D. C., C. Uhl, and E. A. S. Serrao. 1991. Recuperation of a degraded Amazonian landscape - forest recovery and agricultural restoration. Ambio 20:248-255.

Norden, N., M. I. Daws, C. Antoine, M. A. Gonzalez, N. C. Garwood, and J. Chave. 2009. The relationship between seed mass and mean time to germination for 1037 tree species across five tropical forests. Functional Ecology 23:203-210.

Ojima, D. S., K. A. Galvin, and B. L. Turner. 1994. The global impact of land-use change. BioScience 44:300-304.

Otero-Arnáiz, A., S. Castillo, J. Meave, and G. IbarraManriquez. 1999. Isolated pasture trees and the vegetation under their canopies in the Chiapas Coastal Plain, Mexico. Biotropica 31:243-254.

Parrotta, J. A., J. W. Turnbull, and N. Jones. 1997. Catalyzing native forest regeneration on degraded tropical lands. Forest Ecology and Management 99:1-7.

Pascarella, J., T. Aide, and J. K. Zimmerman. 2007. The demography of Miconia prasina (Melastomataceae) during secondary succession in Puerto Rico. Biotropica 39:54-61.

Powers, J. S., J. P. Haggar, and R. F. Fisher. 1997. The effect of overstory composition on understory woody regeneration and species richness in 7-year-old plantations in Costa Rica. Forest Ecology and Management 99:43-54.

Purata, S. E. 1986. Floristic and structural changes during oldfield succession in the Mexican tropics in relation to site history and species availability. Journal of Tropical Ecology 2:257-276.

Roa-Fuentes, L. L., C. Martínez-Garza, J. Etchevers, and J. Campo. 2013. Recovery of soil $\mathrm{C}$ and $\mathrm{N}$ in a tropical pasture: passive and active restoration. Land Degradation and Development. http://dx.doi.org/10.1002/ldr.2197

Rudel, T. K., O. T. Coomes, E. Moran, F. Achard, A. Angelsen, J. C. Xu, and E. Lambin. 2005. Forest transitions: towards a global understanding of land use change. Global Environmental Change-Human and Policy Dimensions 15:23-31.

Schupp, E. W., P. Jordano, and J. M. Gomez. 2010. Seed dispersal effectiveness revisited: a conceptual review. New Phytologist 188:333-353.

Slocum, M. G. 2001. How tree species differ as recruitment foci in a tropical pasture. Ecology 82:2547-2559.

Soto, M., and L. Gama. 1997. La región de Los Tuxtlas: climas. Pages 7-23 in E. González Soriano, R. Dirzo, and V. C. R., editors. Historia natural de Los Tuxtlas. Uiversidad Nacional Autónoma de México, Instituto de Biología, Ciudad de México, D.F., Mexico.

Tobón, W., C. Martínez-Garza, and J. Campo. 2011. Soil responses to restoration of a tropical pasture in Veracruz, south-eastern Mexico. Journal of Tropical Forest Science 23:338-344.

Turner, I. M. 1996. Species loss in fragments of tropical rain forest: a review of the evidence. Journal of Applied Ecology 33:200-209.

Turner, I. M., and R. T. Corlett. 1996. The conservation value of small, isolated fragments of lowland tropical rain forest. Trends in Ecology and Evolution 11:330-333.

Uhl, C., R. Buschbacher, and E. A. S. Serrão. 1988. Abandoned pastures in eastern Amazonia: patterns of plant succession. Journal of Ecology 76:663.

van der Pijl, L. 1982. Principles of dispersal in higher plants. Third edition. Springer Verlag, Berlin, Germany.

Wang, B. C., and T. B. Smith. 2002. Closing the seed dispersal loop. Trends in Ecology and Evolution 17:379-385.

Wright, S. J. 2010. The future of tropical forests. Annals of the New York Academy of Sciences 1195:1-27.

Wright, S. J., A. Trakhtenbrot, G. Bohrer, M. Detto, G. G. Katul, N. Horvitz, H. C. Muller-Landau, F. A. Jones, and R. Nathan. 2008. Understanding strategies for seed dispersal by wind under contrasting atmospheric conditions. Proceedings of the National Academy of Sciences USA 105:19084-19089.

Wunderle, J. M. 1997. The role of animal seed dispersal in accelerating native forest regeneration on degraded tropical lands. Forest Ecology and Management 99:223-235.

Zimmerman, J. K., J. B. Pascarella, and T. M. Aide. 2000. Barriers to forest regeneration in an abandoned pasture in Puerto Rico. Restoration Ecology 8:350-360.

\section{Supplemental Material}

Appendix A

Selection of planted species (Ecological Archives A023-059-A1).

\section{Appendix B}

Recruited species in agricultural pasture of Los Tuxtlas, Mexico (Ecological Archives A023-059-A2). 